\title{
Coping strategies and health promotion through teaching-service integration in the context of the COVID-19 pandemic
}

\author{
Estrategias de afrontamiento y promoción de la salud mediante la integración del enseñanza-servicio \\ en el contexto del pandemia de COVID-19
}

\section{Estratégias de enfrentamento e promoção da saúde através da integração ensino-serviço no contexto da pandemia de COVID-19}

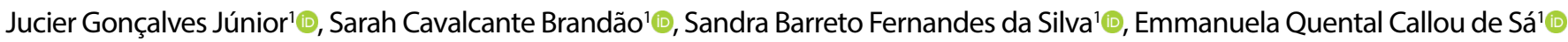

${ }^{1}$ Faculdade de Medicina - Universidade Federal do Cariri

\begin{abstract}
In the current situation related to 2019-nCoV $\beta$-coronavirus, the National Health Authorities have determined the elaboration of contingency plans $(\mathrm{CP})$ that minimize the contagion and allow the functioning of essential activities. The CP presented defines a set of guidelines that allow the adequacy of the response of a public university in Northeast of Brazil linked to the Programa Mais Médicos para o Brasil. Descriptive and qualitative study, type of comment, from the analysis of the data of the CP for the definition of strategies for coping with public health emergencies. The CP consists of ten measures that include assistance via applications/social networks; monitoring of physicians who are at risk; screening of suspected/confirmed cases; production of guides/protocols; $24 \mathrm{~h}$ psychological/technical assistance to physicians working at primary health care and provision of online courses. The methodology proposed provides different models from those trivially presented in academia and is essential to promote health education.
\end{abstract}

Keywords: Coronavirus Infections; Health Promotion; Health Education.

\section{Resumen}

En la situación actual relacionada con el coronavirus $\beta$-nCoV 2019, las Autoridades Nacionales de Salud han determinado la elaboración de planes de contingencia (PC) que minimizan el contagio y permiten el funcionamiento de actividades esenciales. EI PC presentado define un conjunto de pautas que permiten la adecuación de la respuesta de una universidad pública en el noreste de Brasil vinculada al Programa Mais Médicos para o Brasil. Estudio descriptivo y cualitativo, tipo de comment, a partir del análisis de los datos de la PC para la definición de estrategias para hacer frente a emergencias de salud pública. EI PC consta de diez medidas que incluyen asistencia a través de aplicaciones/redes sociales; monitoreo de médicos en riesgo; detección de casos sospechosos/confirmados; producción de guías/protocolos; Asistencia psicológica/técnica las 24 horas a los médicos que trabajan en atención primaria de salud y provisión de cursos en línea. La metodología propuesta proporciona modelos diferentes de los presentados trivialmente en la academia y es esencial para promover la educación sanitaria.

Palabras clave: Infecciones por Coronavirus; Promoción de la Salud; Educación en la Salud.

Como citar: Gonçalves Júnior J, Brandão SC, Silva SBF, Sá EQC. Coping strategies and health promotion through teaching-service integration in the context of the COVID-19 pandemic. Rev Bras Med Fam Comunidade. 2020;15(42):2526. https://doi.org/10.5712/rbmfc15(42)2526

\author{
Autor correspondente: \\ Jucier Gonçalves Júnior. \\ E-mail: juciergjunior@hotmail.com \\ Fonte de financiamento: \\ declaram não haver. \\ Parecer CEP: \\ não se aplica. \\ Procedência: \\ não encomendado. \\ Revisão por pares: \\ Externa. \\ Recebido em: 17/05/2020. \\ Aprovado em: 23/05/2020.
}




\section{Resumo}

Na atual situação relacionada ao 2019-nCoV $\beta$-coronavirus, as Autoridades de Saúde Nacionais determinaram a elaboração de planos de contingência (PC) que minimizem o contágio e permitam o funcionamento das atividades essenciais. O PC apresentado define um conjunto de orientações que permitem a adequação da resposta de uma universidade pública do Nordeste do Brasil vinculada ao Programa Mais Médicos para o Brasil. Estudo descritivo e qualitativo, tipo comment, da análise dos dados do PC para a definição de estratégias para o enfrentamento de emergências de saúde pública. O PC consiste em dez medidas que incluem assistência via aplicativos/redes sociais; monitoramento dos médicos que estão em risco; triagem de casos suspeitos/confirmados; produção de guias/protocolos; 24 horas de assistência técnica e psicológica para os médicos trabalhando na assistência primária à saúde e fornecimento de cursos online. A metodologia proposta oportuniza modelos diferentes daqueles trivialmente apresentados na academia e é essencial para promover a educação em saúde.

Palavras-chave: Infecção pelo Coronavírus; Promoção da Saúde; Educação em Saúde.

The "Programa Mais Médicos para o Brasil" (PMMB), instituted by Law No 12.871, of October 22, 2013, was created in Brazil with the aim of training of human resources in the medical area for the Sistema Único de Saúde (SUS; Unified Health System). The PMMB oversees the provision of physicians in regions where a shortage or absence of these professionals exists, as well as more investments for the construction, reformation and expansion of Unidades Básicas de Saúde (UBS; Basic Health Units), expansion of the number of medical degree places and medical residency places to qualify the training of these professionals. ${ }^{1}$

On December 2019, when the 2019-nCoV $\beta$-coronavirus (COVID-19) pandemic started in Wuhan, China, ${ }^{2,3}$ there was a profound change in the way of organization and social interaction. Health services try to adapt to new and urgent demands, but face difficulties. In this context, the university has a leading role in the training of human resources and as a guide to good practices in health and knowledge production. Thus, the objective was to describe the orientation strategies of the PMMB linked to a public university in Northeast Brazil to its 175 supervising physicians who work in 34 Brazilians cities.

The Faculty of Medicine started as a PMMB Supervisory Institution in 2013. The team consists of family and community physicians (24\%), pathologists (12\%), internists (8\%), cardiologists $(8 \%)$, surgeons $(8 \%)$, and $4 \%$ of hematologists, infectologists, endocrinologists, neurologists, pediatricians and anesthesiologists, totaling two tutors, 20 supervisors and an institutional supporter from the Ministry of Education in the state of Ceara.

There was an initiative to engage medical students in the PMMB through the "Extension Project in Family and Community Medicine" in 2017, based on the regulation by Ordinance 585, of June 15, 2015, which contemplates the program as a space for Permanent Education. Thus, the PMMB allows academics to provide community outreach activities in the UBS linked to physicians participating in the PMMB and a multidisciplinary team, in order to provide them with a practical experience with the family health team's duties; in program management, assisting mentoring in organizing events and monitoring actions; in the research and publication of papers produced within the scope of the PMMB.

The contingency plan (CP) for COVID-19 comprises 10 intervention measures (Table 1), in principle, which will be reevaluated according to national guidelines (Brazilian Ministries of Health, Oswaldo Cruz Foundation, National Health Surveillance Agency, Federal Council of Medicine, Brazilian Medical Association, Ceara State Health Secretary), World Health Organization (WHO) and team of specialists in the region with the support of the Brazilian Nacional Education Ministry. 
Table 1. Description of the ten measures of the Contingency Plan (CP) by PMMB.

\begin{tabular}{|c|}
\hline Remote assistance and supervision by PMMB \\
\hline 1. Conducting periodic virtual meetings involving tutors, supervisors and invited experts. \\
\hline 2. Training for supervisors regarding the management of the COVID-19 and flowchart for patient care in UBS by specialists in the region. \\
\hline 3. Adoption of a longitudinal supervision model offered to doctors program participants by the supervising institution. \\
\hline Telemedicine as a way to support working groups \\
\hline 4. Formation of technical support team. \\
\hline 5. Formation of psycho-emotional support team. \\
\hline Formation of PMMB Partnerships with local institutions \\
\hline 6. Partnership with the Cariri Regional Health Superintendence as an intermediary with the Municipalities linked to the program. \\
\hline Production and summarization of knowledge about COVID-19 for local health departments \\
\hline $\begin{array}{l}\text { 7. Elaboration guidelines for physicians and their health teams subsidized by a technical note from the Health Secretariat of Estado/ } \\
\text { CFM/AMB/ANVISA, adjusted by our team of specialists for the care of users in the UBS due to the risk of contamination of COVID-19. }\end{array}$ \\
\hline Monitoring of physicians and health professionals who are in risk groups \\
\hline $\begin{array}{l}\text { 8. Mapping of the UBS where there are physicians from a risk group and monitoring of cases of COVID-19 in the territory in which they } \\
\text { operate, both by users and by health professionals. }\end{array}$ \\
\hline 9. Redistribution of supervisors in the territory in which they work with the aim of improving the assistance of physicians students. \\
\hline $\begin{array}{l}\text { 10. Sending periodic bulletins to the program management sector, as well as to the University's communication sector regarding coping } \\
\text { of Coronavirus by the "Mais Médicos" Program. }\end{array}$ \\
\hline
\end{tabular}

The first three measures consist of remote assistance and supervision, Google Meets application, with periodic meetings between tutors, supervisors and PMMB scholars, in which there reports are sent, by scholars, which are assessed respectively as to (a) relevance and quality of the information obtained; (b) debates about possible changes or permanence of approaches taken; and (c) re-adaptation of the protocols to the local UBS based on the results found and the protocols of the main health authorities in Brazil and in the world (Table 1). The meetings also serve as an opportunity to offer online training courses in which the scholars have the opportunity to clarify doubts, train their knowledge and update themselves on the COVID-19 pandemic with university professors from the institution or guests. The use of health information and communication technologies offers opportunities to improve clinical care, especially in cases where distance is a critical factor, ${ }^{4}$ in addition to being a strategic alternative to decentralization and improving access to medical care, allowing to reduce costs and displacements. ${ }^{5}$

The fourth and fifth stages (Table 1) consist in the formation of groups for support on Whattsapp, divided as follows: (1) technical support team - formed by infectologists physicians, clinician, cardiologist, rheumatologist and emergency physicians; (2) psycho-emotional support team - formed by psychiatrist and psychologist, as well as a partnership agreement with local psychology courses for psychological support of medical scholar professionals directly linked to assistance.

Neto et al. ${ }^{6}$, demonstrated satisfactory results in reaching the public using the social network as a tool to promote health education. In this way, supervisors can technically prepare themselves to offer a second formative opinion to participating physicians, strengthening the teaching-service integration, which in health units consists of the integrated work of academics, professors, managers and professionals who make up health institutions, aiming to improve individual and collective attention and reorient the educational process and professional training in the health area. ${ }^{7}$ In addition, during pandemics, it is common for health professionals, scientists and managers to focus predominantly on the pathogen and biological risk, in an effort to understand the pathophysiological mechanisms involved and propose measures to prevent, contain and treat the disease. 
In these situations, the psychological and psychiatric implications secondary to the phenomenon, both at the individual and collective levels, tend to be underestimated and neglected, creating gaps in coping strategies and increasing the burden of associated diseases. ${ }^{8}$ In this context, psychology plays an important role in the prevention of mental health problems for professionals and, therefore, psychological shifts for guidance about mental health care, in addition to virtual psychological cares are of paramount importance. ${ }^{9}$

The sixth and seventh stages are the formation of partnerships with the local Regional Health Superintendence, as an intermediary between municipalities and PMMB and the Extension Project in Family and Community Medicine (Table 1), through which there is the production of epidemiological bulletins from the municipalities to the University and production of guidelines for action in UBS for compliance with COVID-19 by specialists from the University for the municipalities. This approach facilitates the entry of clinical and demographic data and information, in order to combat fake news, myths and rumors about the outbreak of COVID-19. The advancement in the use of social media as a means of information has brought with it the challenge of monitoring and responding quickly to false content disseminated on these channels. In this context, the growing movement of discredit traditional communication channels, which encourages adherence to alternative sources, also becomes a public health risk that must be faced. The communication of specialists cannot be restricted to the academic environment and professionals in the field. ${ }^{10}$ This alternative is also in line with the proposed guidelines for medical training in SUS, ${ }^{11}$ because, when integrating an extension project directly to assistance, there is a proposal to link medical training to generalist, humanist, critical stance and reflexive, empowering them to work in the different health services at their different levels of care.

The last three stages (Table 1) are monitoring of physicians and health professionals who are in risk groups, in the areas assigned by the UBS linked to the PMMB, planning to deliver reports to local municipal administrations; and redistribution of medical tutors in the University's coverage area, aiming at better assistance and adequate pedagogical support to the 44 newly graduated scholarship physicians by Notice $n^{\circ} 05$, of March 11, 2020.12

The literature outlines that joint efforts by the State and Universities are necessary to increase the hiring of professionals for support teams, institute action protocols for different social scenarios, ensure the necessary inputs to increase the attendance, especially of individual protection equipment, guarantee training of paramentation and desparamentation to all team professionals. ${ }^{13}$

It is worth noting that difficulties are being encountered in the application of the CP as deficits for resources in health promotion actions with the community; in some situations, there was difficulty in matching schedules with the students 'curriculum and the supervisors' professional routine; in addition, the shift to operating scenarios is also challenging.

It is also important to note that there was no resistance from the second opinion offer to specialists. It is clear that due to the team's cohesion and longitudinal work over the past seven years, a collective commitment of tutors and supervisors to local primary care has been created, even though the training is different. In fact, the second opinion system opened the prerogative for organizations of pedagogical meetings using web conferences through an agenda on Google, sending invitations, moderating activities between participants and speakers, and evaluation processes within the program. 
At the same time, the local administrations received the support offered by the PMMB in a very comprehensive way because, in the current context of the COVID-19 pandemic, many protocols with different approaches and different institutions cause insecurity and make the preparation of contingency plans difficult. Thus, the support of a local team with technical knowledge of the demands of the teams assigned in line with the main national and international guidelines is essential.

The emergence of new diseases has impacts far beyond the cases and deaths they generate. They also create an ideal context that imposes on national public health systems the task of validating their health surveillance and assistance system as for of the opportunity for early detection and the power of response that came in cascading. ${ }^{10}$ Despite the state of pandemic and global alert, health surveillance actions based on the triple alliance between teaching-extension and management can be fundamental, especially when considering particularities of actions in different regions of the world, especially in countries with large dimensions such as the Brazil. Finally, it is noteworthy that the group keeps studying possibilities to better assess the impacts of the PC in the assisted municipalities, as well as there is a research project in preparation phase aiming at this mapping.

\section{REFERENCES}

1. Ministério da Saúde (BR). Programa Mais Médicos para o Brasil. Mais médicos, mais saúde para você [Internet]. Brasília (DF): Ministério da Saúde; 2013; [access in 2020 May 11]. Available from: http://maismedicos.gov.br/conheca-programa

2. Li Q, Guan X, Wu P, Wang X, Zhou L, TongY, et al. Early transmission dynamics in Wuhan, China, of novel coronavirus-infected pneumonia. N Engl J Med. 2020 Mar;382:1199-207. DOI: https://doi.org/10.1056/NEJMoa2001316 DOI: https://doi.org/10.1056/NEJMoa2001316

3. Guo YR, Cao QD, Hong ZS, Tan YY, Chen SD, Jin HJ, et al. The origin, transmission and clinical therapies on coronavirus disease 2019 (COVID-19) outbreak-an update on the status. Mil Med Res. 2020 Mar;7(1):11. DOI: https://doi.org/10.1186/s40779-020-00240-0

4. Zanotto BS, Etges APBDS, Siqueira AC, Silva RSD, Bastos C, Araujo ALD, et al. Avaliação Econômica de um Serviço de Telemedicina para ampliação da Atenção Primária à Saúde no Rio Grande do Sul: o microcusteio do Projeto TeleOftalmo. Ciênc Saúde Coletiva. 2020;25(4):1349-60. DOI: https://doi.org/10.1590/1413-81232020254.28992019

5. Catapan SC, Calvo MCM. Teleconsultation: an integrative review of the doctor-patient interaction mediated by technology. Rev Bras Educ Med. 2020 Mar;44(1):e002. DOI: https://doi.org/10.1590/1981-5271v44.1-20190224.ing

6. Neto EPB, Sales JR, Maciel AHC, Cardoso GYR, Correia DBS, Veloso AFH, et al. Utilização de mídias digitais como meio de educação em saúde no contexto de emergências: extensão universitária. Cidadania em Ação: Revista de Extensão e Cultura. 2018 Jul/Dec;2(2):4758. DOI: https://doi.org/10.5965/25946412222018047

7. Luz AL. Atenção primária como cenário de prática de uma escola médica no Brasil: avaliação da integração ensino serviço [dissertação]. São Luís (MA): Universidade Federal do Maranhão - Programa de Pós-Graduação em Rede em Saúde da Família/CCBS; 2019; [cited 2020 May 11]. Available from: https://tedebc.ufma.br/jspui/bitstream/tede/3070/2/Aldicl\%c3\%a9yaLimaLuz.pdf

8. Ornell F, Schuch JB, Sordi A, Kessler FHP. "Pandemic fear" and COVID-19: mental health burden and strategies. Braz J Psychiatry. 2020 Jun;42(3):232-5. DOI: https://doi.org/10.1590/1516-4446-2020-0008 DOI: https://doi.org/10.1590/1516-4446-2020-0008

9. Grincenkov FR. A Psicologia Hospitalar e da Saúde no enfrentamento do coronavírus: necessidade e proposta de atuação. HU Revista 2020;46:03-e.

10. Lana RM, Coelho FC, Gomes MFDC, Cruz OG, Bastos LS, Villela DAM, et al. Emergência do novo coronavírus (SARS-CoV-2) e o papel de uma vigilância nacional em saúde oportuna e efetiva. Cad Saúde Pública. 2020;36(3):e00019620. DOI: https://doi.org/10.1590/0102$-311 \times 00019620$

11. Winters JRDF, Prado ML, Heidemann ITSB. Nursing education oriented to the principles of the Unified Health System: perception of graduates. Esc Anna Nery. 2016;20(2):248-53.

12. Ministério da Saúde (BR). Edital no 05, de 11 de março de 2020. Chamamento público para adesão de médicos ao programa de provisão de médicos do Ministério da Saúde - Projeto Mais Médicos para o Brasil. Diário Oficial da União, Brasília (DF), 11 mar 2020 ; [access in 2020 May 11]. Available from: http://maismedicos.gov.br/images/PDF/Edital_medico_publicao_DOU_11.03.2020_19ciclo-2.pdf

13. Pinho SB. A Atenção Primária a Saúde no contexto da COVID19. HU Revista. 2020;46:01-e. 